\title{
Taxonomic Redescription of Messor Himalayanus Forel (Hymenoptera: Formicidae), New Report from South India
}

\author{
Presty John ${ }^{1} \&$ K A Karmaly ${ }^{2}$ \\ ${ }^{1}$ s.H College, Thevara, Cochin, India \\ ${ }^{2}$ St.Xaviers College For Women Aluva. India
}

\begin{abstract}
Ants are dominant insects and highly developed social animal. They are widely distributed throughout the world. Currently there are 28 subfamilies and 408 genera. (Bolton et.al, 2007) The species Messor himalayanus Forel belongs to the subfamily Myrmicinae of family Formicidae. The present study was carried out in three places of Kollam district viz. Kuriottumala, Punalur and Yeroor. The ecology of this species ie; nesting pattern, habit, habitat, food preferences, active involvement in day timings and colonial behavior are observed. The species Messor himalayanus Forel resdescribed, compared with other species of Messor and similarities and dissimilarities are also provided. Currently there are only two species of Messor reported from India and only one from South India and the species Messor himalayanus Forel adds a new report to South India.
\end{abstract}

Keywords: Messor himalayanus, Myrmicinae, New report, Resdescription, South India.

\section{Introduction}

The genus Messor was established by Forel in 1890 as subgenus of Aphaenogaster. In 1892d Emery synonimised as Cratomyrmex based on the type-species Cratomyrmex regalis by monotypy, 1895 as subgenus of Stenamma . In 1903 Bingham raised Messor as genus based on the type species Formica Barbara, , in 1917 Veromessor by Forel as subgenus of Novomessor. The genus Veromessor was recently synonymised with Messor (Bolton, 1982). Currently there are 112 species, 49 subspecies in world (Bolton, 2012) . In India there are only two species of Messor. (Himender Bharti,2011)

The genus Messor is commonly known as Harvester ants. Harvester ants are species that regularly store collected seeds in underground granaries (Hölldobler and Wilson, 1990), thus shaping the physical, chemical and hydrological properties of the soil (Cammeraat et al., 2002). The colonies can be often seen in grassy areas where seeds are available. This kind of land forms a suitable place for Messor himalayanus Forel for nest construction. Most of them construct the nest behind the roots of grass.

\subsection{Study site}

\section{Materials And Methods}

The study was performed in a typical grassland area ie; Kuriottumala (Kollam). The soil is mainly sandy. The typical vegetation is composed of herbaceous plants, mostly dominate by grasses.

Specimens were collected by all out search method on the ground. Collected specimens were mounted on rectangular cards and pinned with Asta insect pins of size $38 \mathrm{~mm}$ x 0.53 of 3 (made by Newy Goodman Ltd $\mathrm{U}$ K). Ants up to the genus level by using Stereoscopic binocular microscope (Getner 40x) and species level identification is carried out using Leica MZ6 stereo zoom microscope (Germany), based on taxonomic keys of (Bingham, 1903, Hölldobler \& Wilson, 1990; Bolton, 1994). The unmounted specimens were stored in $70 \%$ alcohol in eppend off tubes and kept in refrigerator for further studies.

\section{Measurements}

AL: Alitrunk length .the diagonal length of the Alitrunk in profile from the point at which the pronotum meets the cervical shield tho the posterior base of the metapleuron

ED Eye diameter: maximum diameter of compound eye measured in oblique lateral view.

F1-F12: Funicular segments, Length of the antennal segments (funnicles) except scape

HL: Head length: maximum distance from the mid-point of the anterior clypeal margin to the mid-point of the posterior margin of the head, measured in full-face view;.

HW: Head width: measured at widest point of the head, in full-face view behind eye-level.

PW: Pronotal width: maximum width of pronotum measured in dorsal view.

SL: Scape length: maximum scape length, excluding basal condyle and neck.. 


\section{Indices}

CI: Cephalic index $(\mathrm{HWx} 100) / \mathrm{HL}$

SI: Scape index (SLX100)/HW

5.1 Worker measurements \& indices

\section{Results}

5.2 Worker minor

$\mathrm{TL}=6.5 \mathrm{~mm} ; \mathrm{HL}=2 \mathrm{~mm} ; \mathrm{HW}=2 \mathrm{~mm} ; \mathrm{CI}=100 \mathrm{~mm} ; \mathrm{SL}=1.5 \mathrm{~mm} ; \mathrm{SI}=75 \mathrm{~mm} ; \mathrm{ED}=0.25 \mathrm{~mm} ; \mathrm{PW}=1 \mathrm{~mm}$;

$\mathrm{AL}=2 \mathrm{~mm}$

5.3 Colour

Head, thorax and abdomen black; antennae, legs reddish brown.

5.4 Sculpture and hair pattern

Yellowish white, abundant, appressed hairs are present all over the body.

Head anteriorly, pronotum above, abdomen, smooth, polished and shining; mesonotum above in profile and laterally, very densely transversely striated; pronotum laterally, head posteriorly, nodes of pedicel rugulose; mandibles longitudinally striated.

\subsection{Head}

Excluding mandibles head square; posterior region of head distinct, emarginated, vertex anteriorly little truncated; antennae 12 segmented with indistinct club, antennal groove distinct, scape of the antennae short, slender, cylindrical, reach upto $3 / 4^{\text {th }}$ from it's insertion to the top of the head; eyes small, round, midlaterally located; ocelli absent; frontal carinae short, distinct, widely divergent; clypeus triangle, slightly emarginated posteriorly, transverse anteriorly; mandibles curved inwards, strong, massive, dentition obsolete.

\subsection{Thorax}

Pronotum and mesonotum forming a single convexity, pronotum forming a shield above, promesonotal groove distinct; mesometanotal groove deep; mesopleuron with single impression in the middle; metanotal spiracle, metapleural gland bulla distinct, metanotum unarmed; coxa of legs rectangular; trochanter thickened in middle, narrowed posteriorly; femur slender not dichromatic.

\subsection{Abdomen}

Two nodes of pedicel distinct, first node anteriorly attenuated, emarginated above, conical; helicium present; second node of pedicel rounded above, as long as broad. Gaster opaque, broadly oval.

\subsection{Plesiotype:}

Worker major N $8^{\circ} 29^{\prime} 18.2872 "$ E $76^{\circ} 55^{\prime} 7.7743 "$, INDIA: Kerala, Trivandrum (Veli) Presty: 20.IV. 2011 [DZSXCA).

5.9 Other materials examined:

2 W: INDIA: Kerala, Kollam (Kuriottumla) Presty John 07. X. 2011,. 2W: INDIA: Kerala, Kasargod (Bekkel) Presty John, 20.I.2011, 2 W: INDIA: Kerala, Kollam (Yeroor) Presty John 26.I.20121W: INDIA: Kerala, Kollam (Punalur) Presty John 19.IV.2012.

5.10 Distribution: INDIA [Kerala: Kollam; Trivandrum; Kasargod);

5.11 Biology: Unknown.

5.12 Habit: Granivorous.

5.13Habitat: Collected from grassy plains.

\section{Discussion}

Messor himalayanus Forel closely resembles with Messor barbarous Linnaeus in having 1. Sides of thorax transversely striate. 2. Abdomen highly polished, smooth and shining.3. Mandibles longitudinally striated. However Messor himalayanus Forel differs from Messor barbarous Linnaeus in having 1. Meatnotum unarmed (in Messor barbarous Linnaeus metanotum is dentate). 2. Pilosity wanting ((in Messor barbarous Linnaeus Pilosity abundant). 3. Head with scattered punctures ((in Messor barbarous Linnaeus head is without punctures). 


\section{Acknowledgement}

We also wish to thank KSCSTE Trivandrum, Kerala for providing the fund for carrying out the work. Also thankful to the Principal's of S.H College Thevara and St. Xavier's College for Women, Aluva for providing necessary facilities for carrying out the work.

\section{References}

[1] Bingham, C. T. The Fauna of British India, including Ceylon and Burma.Hymenoptera, Vol.II. Ants and Cuckoo-wasps.. Taylor and Francis, London (1903) 506 pp

[2] Bolton, B. Afrotropical species of the myrmicine ant genera Cardiocondyla, Leptothorax, Melissotarsus, Messor and Cataulacus (Formicidae). . Bull. Br. Mus. Nat. Hist. (Ent.), 45, . (1982) 307-370 pp.

[3] Bolton, B. Identification Guide to the Ant Genera of the World:. Cambridge, Mass (1994) $222 \mathrm{pp}$.

[4] Bolton, B. Catalogue and Synopsis, in http://gap.entclub.org/ (2012)

[5] Bolton, B., Alpert, G., Ward, P. S. and NeskereckiI, P. BOLTON'S CATALOGUE OF ANTS OF THE WORLD, 1758 - 2005. Compact Disc Edition, Harvard University Press.

[6] Cammeraat L.H., Willott S.J., Compton S.G. and Incoll L .D. 2002. The effects of ants' nests on the physical, chemical and hydrological properties of a rangeland soil in semi-arid Spain. Geoderma (2007).105: 1-20

[7] Emery, C. d. Voyage de M. Ch. Alluaud dans le territoire d'Assinie (Afrique occidentale) en juillet et août 1886. Formicides. Annales de la Société Entomologique de France 60 (1891): (1892) 553-574 pp.

[8] Emery, C.. BeitrŠge zur Kenntniss der nordamerikanischen Ameisenfauna. (Schluss). Zool. Jahrb. Abt. Syst. Geogr. Biol. Tiere, (1895) 8: 257-360 pp.

[9] Forel, A. Fourmis de Tunisie et de l'AlgŽrie orientale rŽcoltŽes et dŽcrites par Auguste Forel. Annales de la SociŽtŽ Entomologique de Belgique. Comptes-rendus (1890) 34: 1xi-lxxvi

[10] Forel, A.. Cadre synoptique actuel de la faune universelle des fourmis. Bulletin de la Société Vaudoise des Sciences Naturelles (1917) 51: 229-253.

[11] Himender Bharti, List of Indian Ants (Hymenoptera:Formicidae), Halters, (2011) Vol 3 79-87pp.

[12] Hölldobler B. and Wilson E.O The Ants. The Belknap Press of Harvard University Press, Cambridge, Massachusetts. (1990). 732 pp.
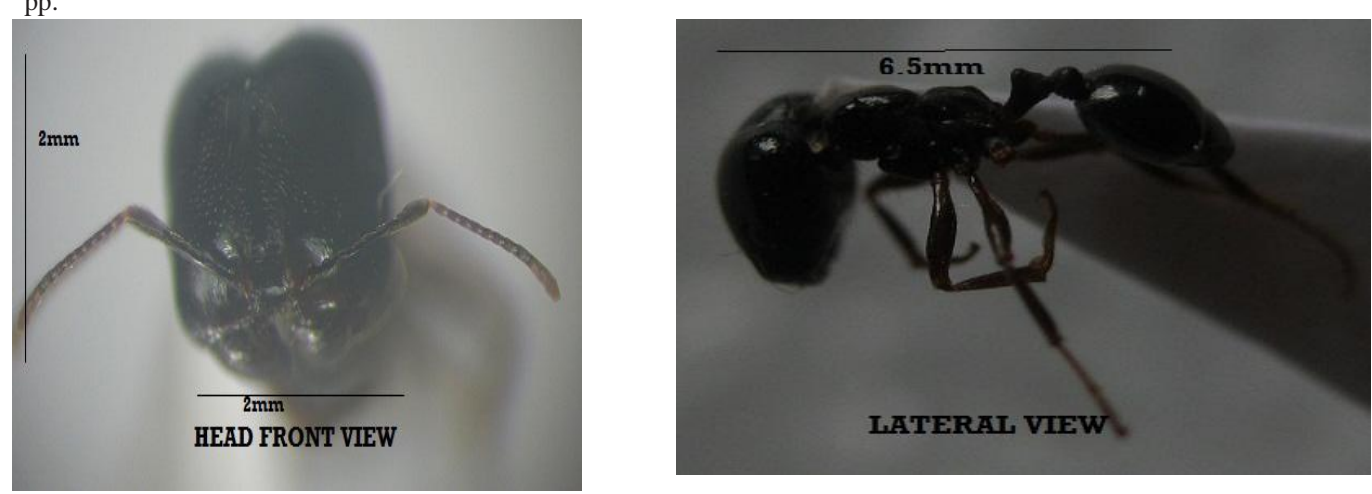